\title{
Intertidal barnacle distribution: a case study using multiple working hypotheses
}

\author{
Gilles Miron*, Bernard Boudreau, Edwin Bourget
}

GIROQ, Département de Biologie, Université Laval, Québec, Québec G1K 7P4, Canada

\begin{abstract}
The roles of larval supply, selection of habitat, availability of space, larval physiological condition, and early post-settlement mortality in determining vertical distribution patterns of the barnacle Semibalanus balanoides (L.) were simultaneously examined in Passamaquoddy Bay, New Brunswick, Canada. Pump samples and settlement surveys showed that about $60 \%$ of planktonic cyprids were collected from 1.5 to $4.0 \mathrm{~m}$ depth, while over $90 \%$ of newly settled cyprids colonized low intertidal levels. Selection of habitat by cyprids and patterns of settlement were studied using precolonized planks that had been previously placed to obtain various periphyton gradients. These planks precolonized at the low, mid-, and high intertidal levels and placed in different orientations, induced variations in the distribution of newly settled cyprids. For example, vertical planks turned upside down had fewer settlers at low intertidal levels compared to surfaces maintained in the same orientation at the same level. When placed horizontally at the same level, sections precolonized at the low intertidal level collected more larvae than sections initially placed at the high and mid-intertidal levels. We used the triacylglycerol/cholesterol ratio (TAG/CHOL) as a measure of physiological condition in planktonic and newly settled cyprids, and newly metamorphosed spat. The TAG/CHOL ratio in planktonic cyprids decreased over the sampling period, but there was no variability with position in the water column. For newly settled cyprids and newly metamorphosed spat, the TAG/CHOL ratio increased with decreasing intertidal level. Quadrats freed of conspecific adults were colonized by more cyprids than were uncleared controls. Early post-settlement mortality was greater in uncleared than in cleared quadrats, but this effect varied with intertidal level. Early post-settlement mortality increased with increasing intertidal level in cleared quadrats, while it did not significantly vary in uncleared controls. The present study shows that the vertical distribution of $S$. balanoides on the shore results from a complex relationship involving larval supply, selection of habitat, availability of space, and early post-settlement mortality. We also present the first evidence of correlations between larval physiological condition and early vertical distribution in $S$. balanoides
\end{abstract}

KEY WORDS: Barnacles · Semibalanus balanoides · Vertical distribution · Larval supply · Larval settlement - Lipid condition. Selection of habitat. Availability of space - Early post-settlement mortality Recruitment

\section{INTRODUCTION}

Research in marine benthic ecology has been characterized by numerous attempts to model population and community dynamics. Based on a wide variety of experimental field studies (e.g. Connell 1961, 1970, Dayton 1971, Paine 1974, Menge 1976), modelers have used factors such as environmental harshness (e.g.

\footnotetext{
- Present address: Département de Biologie, Université de Moncton, Moncton, Nouveau-Brunswick E1A 3E9, Canada.

E-mail: mirong@umoncton.ca
}

desiccation), resource availability (e.g. food, space), competition, predation, and various stochastic variables (e.g. physical disturbances) as driving forces to explain variations in the distribution and abundance of marine organisms on rocky shores (e.g. Connell 1975, Menge \& Sutherland 1976, Paine 1977, but see Underwood \& Denley 1984). In general, these conceptual models have focused on post-settlement mechanisms to explain population and community dynamics (Grosberg 1982, Underwood \& Fairweather 1989). However, most marine invertebrates living in temperate and tropical regions exhibit complex life histories involving 
a planktonic phase (Thorson 1950, Mileikovski 1971, Scheltema 1986). This planktonic phase facilitates dispersal and is particularly important for sessile species. For example, empirical studies have shown that population size and distribution patterns of several species are determined by the dispersal abilities of the larvae (e.g. de Wolf 1973, Grosberg 1982, Caffey 1985, Connell 1985, Gaines \& Roughgarden 1985, Gaines et al. 1985, Minchinton \& Scheibling 1991, Miron et al. $1995)$ and by active exploration of the substrata, which may lead to permanent attachment (e.g. Keough \& Downes 1982, Yule \& Walker 1987, Mullineaux \& Butman 1991, Miron et al. 1996, Walters et al. 1999). Accordingly, pre-settlement factors (e.g. larval supply, larval behaviour) have been introduced in experimental and theoretical ecology over the last decade (Lewin 1986, Menge \& Sutherland 1987, Roughgarden et al. 1987, 1988, Young 1987, 1990, Underwood \& Fairweather 1989, Grosberg \& Levitan 1995). It is now known that population and community dynamics in marine environments are influenced by processes acting at various spatio-temporal scales: (1) during planktonic larval dispersal, (2) during settlement, and (3) after settlement until adulthood (e.g. de Wolf 1973, Keough \& Downes 1982, Bourget 1988, Boudreau et al. 1990, Minchinton \& Scheibling 1991, Bertness et al. 1992).

On rocky intertidal shores, the abundance of adult barnacles usually varies along the vertical axis (e.g. Strathmann \& Branscomb 1979, Grosberg 1982, Minchinton \& Scheibling 1991, Miron et al. 1995). Different models can explain the observed patterns: (1) settlers may not reach high and low shore levels in the same proportion, because of variations in the duration of immersion or undefined physical influences on larval supply, (2) larval supply is relatively uniform but individual cyprids demonstrate differential capacity to detect cues and/or preferences for particular shore levels possibly related to habitat cues, and (3) differential post-settlement mortality associated with shore level. In general, these models involve passive and active phases (Bourget 1988, Mullineaux \& Butman 1991, Waiters 1992, Boudreau et al. 1993a, Miron et al. 1996). Once surface contact has been made (usually passively), larvae actively respond to exogenous factors such as biological, chemical, and physical cues, singularly or in combinations, to find a proper settlement site (Crisp 1974, Bourget 1988, Miron et al. 1996, Walters et al. 1999). Selection of habitat may also depend on endogenous factors such as the physiological condition of larvae (Lucas et al. 1979, Boudreau et al. 1993b). However, little information is available on the relationship between larval physiological condition (e.g. starvation, energy expenditure) and settlement and recruitment processes.
Dispersal and settlement of marine invertebrates, including barnacles, have been extensively studied (for reviews, see Crisp 1974, Hadfield 1986, Bourget 1988, Morse 1990, Pawlik 1992, Hunt \& Scheibling 1997). However, most empirical studies test 1 hypothesis at a time. We believe that multiple hypotheses tested simultaneously will provide insight into the relative importance of mechanisms controlling distribution and abundance. The present study, using multiple working hypotheses (Platt 1964, Chamberlin 1965, but see Underwood 1990, 1991), examines how larval supply, selection of habitat, availability of space, larval physiological condition and early post-settlement mortality may influence the vertical distribution of settling larvae and spat survival on the Atlantic coast of Canada for the barnacle Semibalanus balanoides (L.). To our knowledge, this is the first field study simultaneously testing different hypotheses likely to explain the dynamics of recruitment of sessile invertebrates and how larval lipid content (larval physiological condition) may influence the vertical distribution of recruits.

\section{METHODS}

Study site. The study was conducted from 27 March to 25 May 1993 on the Atlantic Coast of Canada, at St. Andrews, New Brunswick $\left(46^{\circ} 04^{\prime} \mathrm{N}, 67^{\circ} 03^{\prime} \mathrm{W}\right)$. The study site was characterized by a mean tidal amplitude of $5.6 \mathrm{~m}$ and a mean water level of $4.1 \mathrm{~m}$ above the lowest water level of spring tides (LWST). A complete description of the study area is available in Thomas et al. (1983) and Chabot \& Bourget (1988). All samples were collected near the town pier which stands on a muddy tidal flat. During the sampling season, water temperature and salinity ranged from 4 to $9^{\circ} \mathrm{C}$ and 28.55 to $30.12 \%$, respectively.

Distribution of cyprids in the plankton and on the substrata. Plankton samples were collected by filtering $2000 \mathrm{l}$ of water through a $64 \mu \mathrm{m}$ mesh plankton net using a centrifugal pump (Monark BSGF-8) from 5 different depths (surface, 0.5, 1.0,1.5, and $4.0 \mathrm{~m}$ ). At each depth, 1 water sample was pumped for $5 \mathrm{~min}$ at a calibrated flow rate of $400 \mathrm{l} \mathrm{min}^{-1}$ during the day. All samples were taken from the east side of the pier at high tide during slack water. Maximum water depth at the sampling location was about $4.6 \mathrm{~m}$ during the settlement season. Samples used for density measurements (n $\mathrm{I}^{-1}$ ) were fixed in $4 \%$ buffered formalin immediately after collection. Vertical distribution of cyprids in the plankton and temporal variation in cyprid abundance were monitored daily between 14 and 24 May (except 19 May). Nocturnal cyprid distribution was determined on 17 May, the date of peak abundance during the 
study period. Vertical distribution and abundance ( $\mathrm{n} \mathrm{m}^{-2}$ ) of newly settled cyprids were determined from samples (5 $\times 10 \mathrm{~cm}$ permanent quadrats) collected daily between 9 and 25 May on the pilings of the pier at high, mid-, and low intertidal levels, defined as 4.11 , 2.90 , and $1.68 \mathrm{~m}$ above LWST, respectively. Three replicate samples were taken at each level. Water height was monitored throughout the settlement period with a tidal gauge moored near the pier.

Settlement experiments: precolonization by periphyton. Precolonization by periphyton was conducted by placing 2 sets of $3.66 \times 0.15 \times 0.03 \mathrm{~m}$ spruce planks on the pier on 27 March 1993 (Fig. 1). A first set of 18 planks was installed vertically, in the shade, perpendicular to tidal flow to obtain a vertical periphyton gradient. A second set of 15 planks was installed horizontally to obtain a homogenous, level-specific periphyton colonization. This set was placed at midintertidal level (between 2.40 and $3.40 \mathrm{~m}$ above LWST). Precolonization lasted $\sim 40 \mathrm{~d}$. The precolonized planks were spatially rearranged on 6 May for the barnacle settlement experiments (see Fig. 1).

Periphyton on precolonized planks was sampled on 6 May. Vertical planks were divided into 3 equal zones as defined above (high, mid-, and low intertidal levels). Periphyton was collected from 3 successive $10 \times 10 \mathrm{~cm}$ quadrats using a soft toothbrush. Surfaces were brushed by sweeping from top to bottom 3 times. A single toothbrush was used for each level. Toothbrushes were rinsed regularly in a jar filled with $30 \mathrm{ml}$ of filtered $(0.5 \mathrm{~mm})$ seawater. A total of 27 samples was collected ( 3 sites $\times 3$ intertidal levels $\times 3$ replicates). Samples were fixed in a $4 \%$ buffered formalin and $2 \%$ Lugol solution. The periphyton on horizontal planks was also examined. Three successive $10 \times 10 \mathrm{~cm}$ quadrats were brushed from each plank section. Similarly, 27 samples were collected $(3$ sites $\times 3$ sections $\times 3$ replicates). Algal cells were identified and counted at a magnification of 400 with a Wild M40-58056 inverted microscope. Comparisons among sections of vertical and horizontal planks were made using relative abundances of the dominant algal genera ( $\%$ of total number) collected from the planks (mainly diatoms and the green alga Ulothrix sp.). The filamentous green alga Ulothrix sp. was quantified by counting the number of individual cells rather than the number of filaments or colonies to facilitate comparison with diatom cells also counted individually.

Settlement experiments: influence of selection of habitat. Two experiments were designed to examine the response of settling cyprids to periphyton components usually encountered at high, mid-, and low shore levels. In Expt 1, 4 treatments were used: precolonized vertical planks placed in the original vertical position (VV), precolonized vertical planks placed in the oppo- site direction (planks turned upside down) (VUD), precolonized horizontal planks from mid-intertidal level placed vertically (precolonized control planks) (HV), and virgin planks placed vertically (uncolonized control planks) (UV). In this experiment, the upper third of the plank $\left(0.18 \mathrm{~m}^{2}\right)$ was considered as high intertidal the mid-third as mid-intertidal, and the lower third as low intertidal level (Fig. 1). The 3 section centres were $4.11,2.90$, and $1.68 \mathrm{~m}$ above LWST, respectively. The planks were immersed at high tide and emerged at low tide. A total of 12 planks was used ( 4 treatments $x$ 3 sites).

In Expt 2, 3 treatments were used: precolonized vertical planks placed horizontally (VH), precolonized horizontal planks (precolonized control planks) placed

\section{PRECOLONIZATION OF SUBSTRATA BY PERIPHYTON}

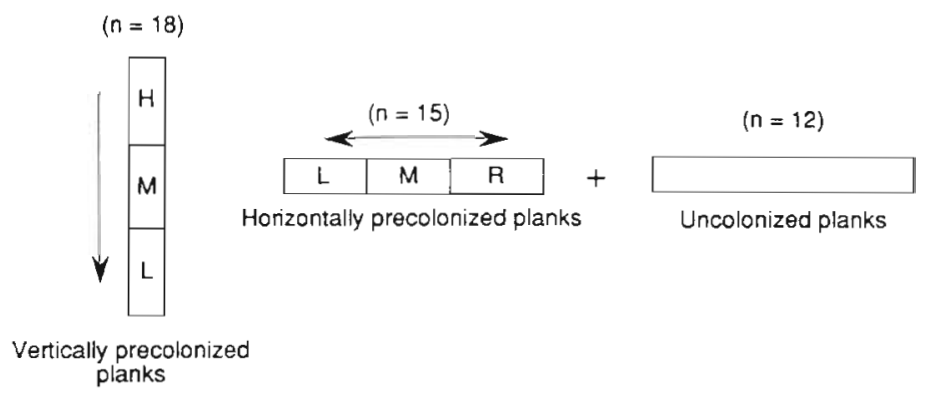

BARNACLE SETTLEMENT EXPERIMENTS

Experiment 1

Experiment 2
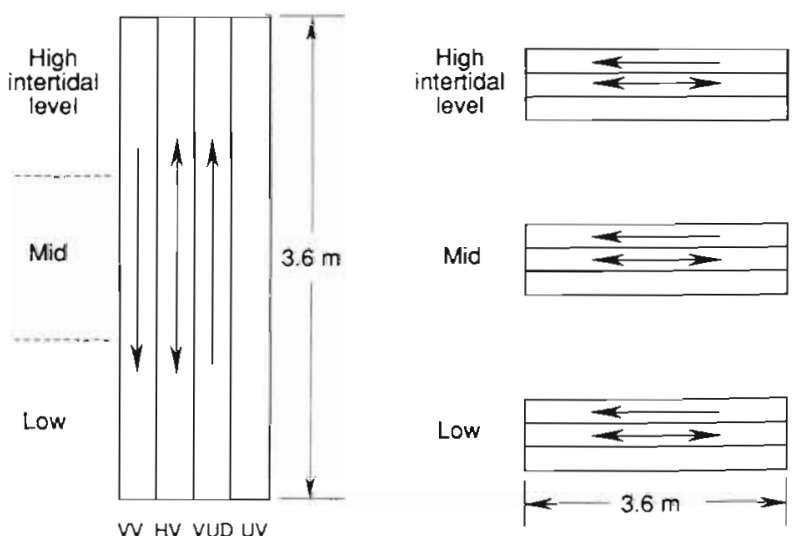
$\mathrm{VH}$
$\mathrm{HH}$ $\mathrm{HH}$
$\mathrm{UH}$

Fig. 1. Diagram illustrating the arrangement of planks for substrata precolonization by periphyton (27 March to 6 May) and settlement Expts 1 and 2 ( 6 to 25 May). Arrows indicate the direction of periphyton gradients $(\leftrightarrow$ : no gradient $\rightarrow$ : increasing periphyton density). H, M, and L are high, mid-, and low intertidal levels, respectively, on precolonized vertical planks. L, M, and $\mathrm{R}$ are left, middle, and right sections, respectively, on precolonized horizontal planks 
in the same position at all 3 levels $(\mathrm{HH})$, and virgin planks (uncolonized control planks) placed horizontally at all 3 levels (UH). Planks were installed so that there were 3 treatments at all 3 intertidal levels (high, mid-, and low) (Fig. 1). Planks were divided into 3 equal $0.18 \mathrm{~m}^{2}$ sections to determine the number of settled larvae (left, middle, and right sections). A total of 27 planks was used ( 3 treatments $\times 3$ intertidal levels $\times 3$ sites)

Since the working area under the town pier was small (i.e. limited number of pilings in an environmentally homogenous zone), we decided to use all possible treatments at each site. Sites corresponded to pilings parallel to the water line. These sites were used and considered as blocks of homogenous experimental units for the statistical analyses. Densities of newly settled cyprids and newly metamorphosed spat $\left(\mathrm{n} \mathrm{m}^{-2}\right)$ were counted daily between 9 and 25 May. Individuals were removed with a scalpel after counting.

Larval physiological condition. The physiological condition of planktonic and newly settled cyprids, as well as that of newly metamorphosed spat of Semibalanus balanoides, was assessed using an index based on lipid composition. In many invertebrate larvae, neutral lipids, such as triacylglycerol (TAG), are the primary endogenous energy reserves used for basal metabolism (e.g. egg differentiation, larval behaviour, larval metamorphosis, growth; Holland 1978, Gallager \& Mann 1986, Ouellet et al. 1992). The quantity of TAG, however, cannot be solely used to estimate the physiological condition of larvae because of its dependency on larval size (Gallager \& Mann 1986). Alternatively, TAG content can be expressed relative to sterol content to yield a ratio that compensates for the size dependency of TAG (Fraser 1989). We used the ratio of triacylglycerol to cholesterol (TAG/CHOL) to evaluate the physiological condition of planktonic and newly settled cyprids, and newly metamorphosed spat. A total of 15 individuals was used per vial (sample) for lipid-class analyses. Samples $(n=3)$ were placed into liquid nitrogen immediately upon collection and stored at $-70^{\circ} \mathrm{C}$. Samples were analysed in the laboratory in early July 1993. TAG and CHOL lipids were separated and quantified using thin-layer chromatography and flame ionization detection (TLC/FID) (Ackman et al. 1990). The solvent system for lipid separation was dichloroethane-chloroform-acetic acid-isopropanol (92/8/0.10/0.15, v/v/v/v). Lipid samples were spotted onto silicate-covered thin quartz rods (chromarods) and run on an Iatroscan Mark $\mathrm{V}$ analyser (Iatron Laboratories Inc., Tokyo, Japan). The air-flow rate was $2000 \mathrm{ml} \mathrm{min}^{-1}$, hydrogen pressure was $0.9 \mathrm{~kg} \mathrm{~cm}^{-2}$, and scan speed was $30 \mathrm{~s} \mathrm{rod}^{-1}$ Each lipid sample was spotted onto 2 chromarods and the mean value was calculated after development. TAG and CHOL were cali- brated using standard curves from solutions of standard neutral lipids (Ackman et al. 1990). We determined temporal (11, 16, and 22 May) and spatial (16 May) variations in the physiological condition index for planktonic cyprids. Newly settled cyprids and newly metamorphosed spat were collected on 7 May for lipid analyses from the pier's pilings at the 3 intertidal levels. Newly settled cyprids were collected between $07: 00$ and 10:00 h, while newly metamorphosed spat were collected between 18:30 and 20:30 h.

Influence of space availability on cyprid settlement and early post-settlement mortality. This experiment was designed to evaluate the influence of adult barnacle abundance on settlement of conspecific larvae. Newly settled cyprids were counted daily on the pilings of the pier from 8 to 24 May (except 19 May) at the 3 levels specified earlier (high, mid-, and low). Newly settled cyprids were counted in two $5 \times 10 \mathrm{~cm}$ permanent quadrats ( 3 replicates). The \% cover of adults was between 50 and $75 \%$. All adult barnacles were removed from 1 of the 2 quadrats on 6 May with a scalpel (cleared quadrat), while the other was left undisturbed (uncleared quadrat). The new cohort of cyprids was not removed from either type of quadrat. The variables measured were daily number of newly settled cyprids $\left(\mathrm{n} \mathrm{m}^{-2}\right)$ and early post-settlement mortality (\%). The latter, which was estimated from daily photographs (all quadrats), was calculated as the difference between the original number of settled cyprids at the start of the experiment ( 8 May) and the number of individuals of the initial cohort remaining at the end of the experimental period (24 May), expressed as a percentage of the original number of newly settled cyprids. A total of 18 quadrats was monitored (2 treatments $\times 3$ intertidal levels $\times 3$ replicates)

Data analysis. One-way ANOVAs were used to examine the effect of depth on larval abundance over a 10 d period ( $n=10$ ), as well as to examine spatial and temporal variations in the physiological condition index of planktonic and newly settled cyprids, and newly metamorphosed spat. A $2 \times 5$ contingency table was used to test possible interactions between depth and time of day (day vs night distribution of planktonic cyprids) on data collected on 17 May. A 1.-way ANOVA was also used to examine the effect of intertidal level on the relative abundance (\%) of each algal group on precolonized planks. Data were normalized using angular transformations (Zar 1984).

Split-plot factorial (SPF) ANOVAs (Kirk 1982) without replication were used for all settlement experiments addressing the selection of habitat by cyprids (plank treatments). Settlement data were all log-transformed for normality requirements in these analyses. In Expt 1, an SPF- $4 \times 3$ design was used to evaluate the impact of the vertical plank treatment on newly settled 
cyprid abundance at 3 intertidal levels. The 4 levels of plank treatments were randomly assigned for each site. In this statistical analysis, the whole plot treatment corresponded to the intertidal level while the subplot treatment corresponded to the experimental plank treatment. The absence of replicate in our design forced us to use the site $x$ intertidal level interaction as an error term for site and intertidal level factors in the SPF ANOVA. Since sites (blocks) were all similar (i.e. pilings were all similar in shape, close to one another and within a homogenous area), it was reasonable to expect no significant interactions between the sites and the intertidal levels. The highest order interaction having been 0 , the interpretation of the analysis should then have been valid (Montgomery 1991. Underwood 1997). The error term used for the plank treatment factor and plank treatment $x$ intertidal level interaction was the sub-plot error which corresponded to site $x$ plank treatment and site $\times$ intertidal level $\times$ plank treatment interactions. In Expt 2, an SPF-33×3 design was used to evaluate the effect of the horizontal plank treatment on newly settled cyprid abundance at 3 intertidal levels. The 3 levels of plank treatment were randomly assigned for each intertidal level. The whole plot treatment corresponded to the intertidal level while the sub-plot treatment corresponded to the plank treatment. In this analysis, plank section corresponded to a 'sub' sub-plot treatment. Again, different error terms were used because of the absence of replicates in the experimental design. The site $x$ intertidal level interaction was used as the error term for site and intertidal level factors. The triple interaction site $x$ intertidal level $\times$ plank treatment was used with the double interaction site $\times$ plank treatment as the error term for the plank treatment factor and the intertidal level $\times$ plank treatment interaction. Finally, the error term used for the plank section factor and subsequent interactions (plank section $\times$ intertidal level, plank section $\times$ plank treatment and plank section $\times$ intertidal level $\times$ plank treatment) was the 'sub' sub-plot error which corresponded to site $\times$ plank section, site $\times$ intertidal level $\times$ plank section, site $\times$ plank treatment $\times$ plank section and site $\times$ intertidal level $\times$ plank treatment $\times$ plank section interactions.

A repeated-measures ANOVA was used in Expt 3 to evaluate the effect of the presence or absence of adults on newly settled cyprid abundance at 3 intertidal levels. Temporal dependence (sampling day factor) was considered in the analysis since permanent quadrats were used during the experimental period ( 8 to 24 May). The temporal dependence was confirmed with the SAS (1988) Model Fitting Information procedure (Null Model LRT: $\chi^{2}=152.64, \mathrm{df}=1 ; \mathrm{p}<0.0001$ ). In the ANOVA, the temporal dependence was analyzed through an auto-correlation structure (Covari- ance Parameter Estimates: REML procedure [SAS 1988]). Settlement data were normalized using square root transformations (Sokal \& Rohlf 1981). A 2-way ANOVA was used to examine the effect of cleared and uncleared treatments on mortality at 3 intertidal levels. Mortality data $(\%)$ were normalized using angular transformations.

When appropriate, LS Means tests (SA.S 1988) were used to detect significant differences between means after ANOVAs.

Linear correlations ( $\mathrm{r}$ ) were used to examine the relationships between different sets of variables corresponding to the low depth levels: near the bottom for planktonic cyprids, low intertidal levels for newly settled cyprids and newly metamorphosed spat. The relationships tested were: (1) among abundance at each life history stage, (2) among Ulothrix sp. relative abundance (\%) and newly settled cyprid abundance, (3) among physiological condition index at each life history stage, and (4) among physiological condition index and early post-settlement mortality (\%).

\section{RESULTS}

\section{Distribution of planktonic and newly settled cyprids}

The density of planktonic cyprids peaked on 17 May (Fig. 2). Cyprids collected on that day (lowest tide during the sampling period) accounted for $>50 \%$ of the total number of cyprids collected from 14 to 24 May. Overall, cyprids were predominantly suprabenthic (Fig. 3A) with $60 \%$ of individuals collected each day $(\mathrm{n}=10 \mathrm{~d})$ from depths $\geq 1.5 \mathrm{~m}$ below the surface $\left(F_{4,45}=\right.$ $3.39, \mathrm{p}=0.018$ ). Vertical distribution (17 May) varied over $24 \mathrm{~h}\left(\chi^{2}=402.99\right.$, $\left.\mathrm{df}=4, \mathrm{p}<0.001\right)$. During daylight $(\sim 10: 30 \mathrm{~h})$, abundance peaks were at 0.5 and $1.5 \mathrm{~m}$ depths, while at night $(-22: 30 \mathrm{~h})$ the abundance increased gradually with depth (Fig. 3B).

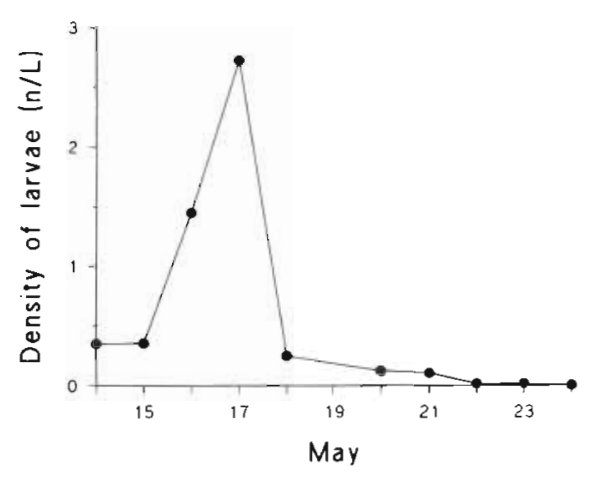

Fig. 2. Daily density of planktonic cyprids of Semibalanus balanoides during the 1993 settlement period. Values were integrated $(\Sigma)$ over the entire water column (no replication) 

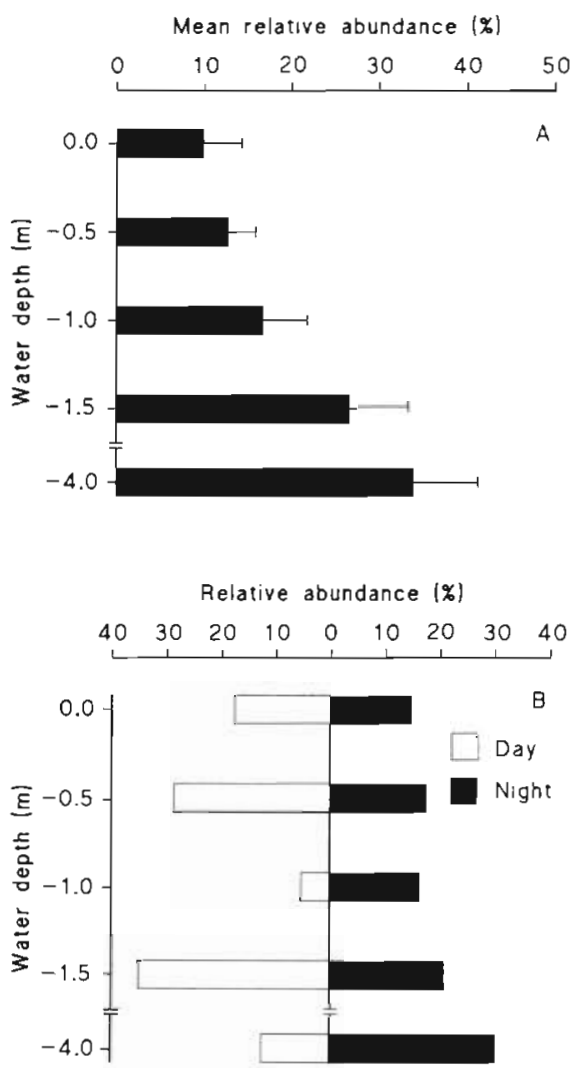

Fig. 3. (A) Daily vertical distribution of planktonic cyprids of Semibalanus balanoides observed during the sampling period (mean relative abundance $\pm \mathrm{SE}_{i} \mathrm{n}=10$ ). (B) Day and night vertical distribution of planktonic cyprids observed on 17 May (no replication)

Newly settled cyprids were monitored every day from 9 to 25 May (Fig. 4). There was an important settlement peak on 17 May, and 2 minor peaks on 20 and 23 May. Newly settled cyprids increased with decreasing intertidal level (Fig. 5). Over $90 \%$ of newly settled cyprids were from low intertidal levels. During the settlement period ( 9 to 25 May), high, mid-, and low intertidal levels were emerged $88.64,57.21$, and $39.16 \%$ of the time, respectively.

\section{Settlement experiments}

Periphyton components on precolonized planks

Diatoms were well represented at all intertidal levels on the precolonized planks. The major genera observed were Achnanthes, Cocconeis, Navicula, Striatella, and Synedra. The relative abundance $(\%)$ of CocConeis, Navicula, and Synedra spp. (Fig. 6A) decreased with decreasing intertidal level $\left(F_{2,23}=29.84, p<0.001\right.$;

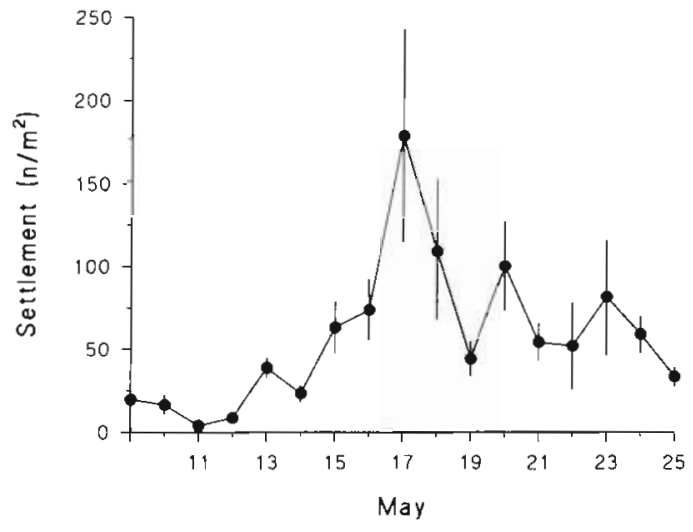

Fig. 4. Daily density (means $\pm S E ; n=3$ ) of newly settled cyprids of Semibalanus balanoides integrated $(\Sigma)$ over all intertidal levels during the sampling period

$F_{2,23}=13.04, \mathrm{p}<0.001 ; F_{2,23}=52.27, \mathrm{p}<0.001$, respectively), while the relative abundance of Achnanthes and Striatella spp. did not vary significantly with intertidal level $\left(F_{2,23}=3.24, \mathrm{p}=0.058 ; F_{2,23}=1.55, \mathrm{p}=0.234\right.$, respectively). The relative abundance of the filamentous green alga Ulothrix sp. significantly increased with decreasing intertidal level $\left(F_{2,23}=35.64, p<\right.$ 0.001 ), outnumbering diatoms at levels below $3.5 \mathrm{~m}$ above LWST. The relative abundance of all groups was similar on horizontal planks and mid-intertidal level vertical planks (Fig. 6B). There was no variation in periphyton composition and abundance among plank sections (Cocconeis: $F_{2,24}=0.42, p=0.662$; Striatella: $F_{2,24}=0.90, \mathrm{p}=0.421 ;$ Navicula: $F_{2,24}=0.36, \mathrm{p}=0.702$; Synedra: $F_{2,24}=0.55, \mathrm{p}=0.581 ;$ Achnanthes: $F_{2,24}=$ $0.06, \mathrm{p}=0.937$; Ulothrix: $F_{2,24}=0.26, \mathrm{p}=0.771$ ).

\section{Selection of habitat}

In both plank experiments, sites did not influence settlement intensity (Tables $1 \& 2$ ). Since no replication was used in the experimental design, sites were used as replicates to estimate a mean $( \pm \mathrm{SE}$ ) settlement response (see Figs. $7 \&$ 8). In the vertical plank experiment (Fig. 7), intertidal level and plank treatment significantly affected the number of newly settled cyprids (Table 1). However, a significant interaction effect between plank treatment and intertidal level was also observed during settlement. At high intertidal level (Fig. 7), inverted planks (VUD planks) were significantly colonized by a greater number of cyprids than VV planks ( $\sim 4 \times$ more $_{i}$ Table 1 . Interaction). This settlement response contrasted with observations at the low intertidal level, where VV planks were significantly colonized by a greater number of individuals com- 


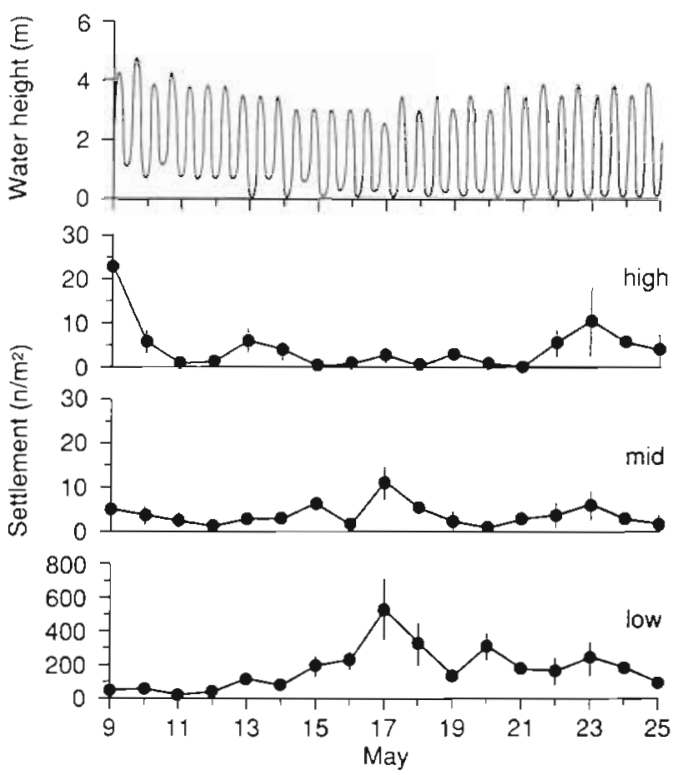

Fig. 5. Daily density (means $\pm \mathrm{SE}_{;} \mathrm{n}=3$ ) of newly settled cyprids of Semibalanus balanoides at high, mid-, and low intertidal levels during the sampling period. Water height variations monitored throughout the sampling period are also presented

pared to any other treatments. At this level, VV planks outnumbered VUD planks by a factor of 7. Although variations among VUD, HV, and UV treatments were not significant regardless of intertidal level (Table 1: Interaction), there were generally more cyprids on HV planks (precolonized control planks) than on UV planks (virgin planks) (Fig. 7). Within the HV treatment, newly settled cyprids increased with decreasing intertidal level (Fig. 7), despite these planks being homogenously precolonized by the periphyton community.

In the horizontal plank experiments (Fig. 8), intertidal level, plank treatment and section of plank all significantly affected the distribution of newly settled cyprids (Table 2). No interaction effect between plank treatment and intertidal level was observed. All interactions in which plank section was involved, however, were significant (Table 2). Overall, settlement on the left section of $\mathrm{VH}$ planks (precolonized at low intertidal level) was greater than on the middle and right plank sections, at both mid- and low intertidal levels (Fig. 8, Table 2: Interaction). We found no significant variation with plank section at high intertidal level. When significant, settlement was always more important on $\mathrm{HH}$ planks than on UH planks at mid- and low intertidal levels. As previously noted, the precolonized horizontal control planks (HH treatment) showed that settlement increased from high to low intertidal levels (Fig. 8).

\section{Physiological condition of cyprids and newly metamorphosed spat}

The physiological condition of planktonic cyprids (TAG/CHOL ratio) significantly varied over time (Fig. 9A). The ratio decreased substantially between 11 and 16 May, then was relatively constant between 16 and 22 May $\left(F_{2,6}=8.32, p=0.041\right)$. There was no significant difference in the mean TAG/CHOL ratio with depth $\left(F_{4,10}=0.58, \mathrm{p}=0.345\right)$ (Fig. 9B). The TAG/CHOL ratio in newly settled cyprids $\left(F_{2,6}=10.55, p=0.023\right)$ and newly metamorphosed spat $\left(F_{2,6}=10.04, \mathrm{p}=0.027\right)$ decreased with increasing intertidal height (Fig. 10).

\section{Influence of space availability on cyprid settlement and early post-settlement mortality}

A greater number of cyprids colonized quadrats that had been cleared of adult conspecifics compared to
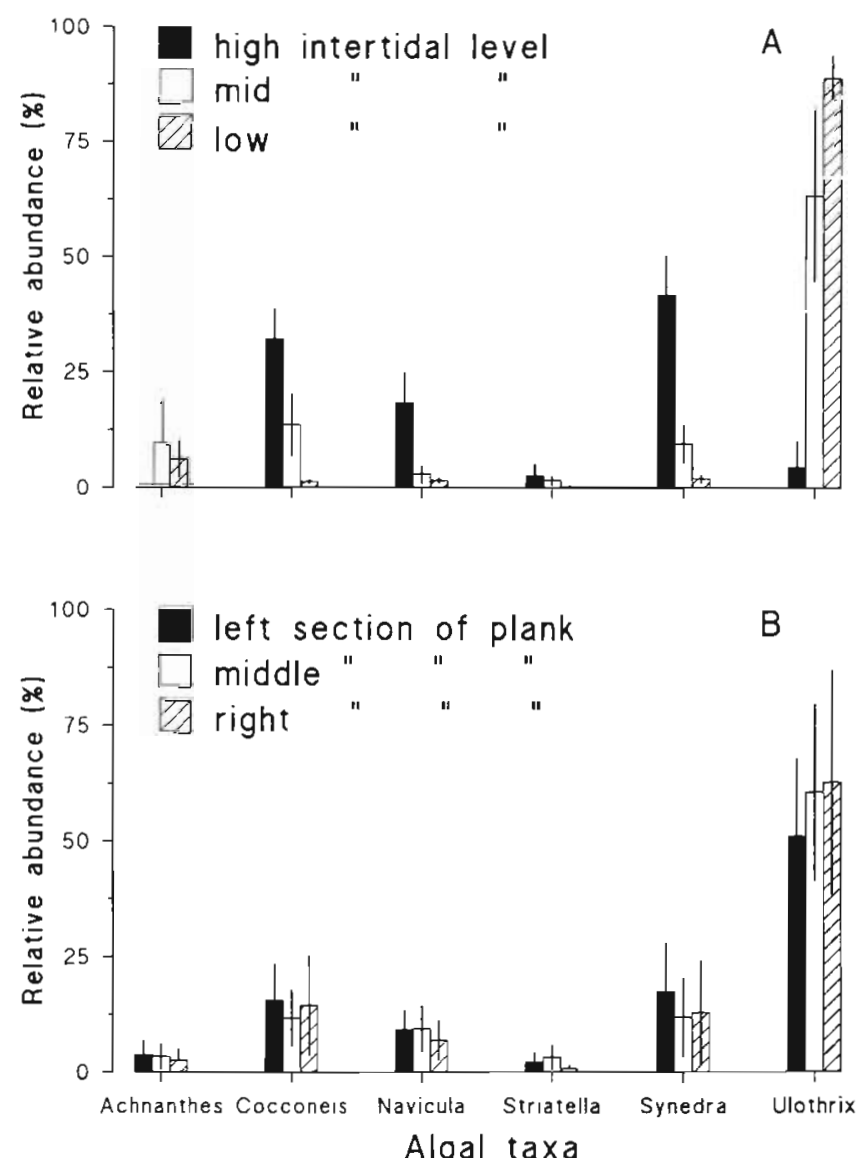

Fig. 6. Relative abundance (mean percentage $\pm S E ; n=3$ ) of major algal taxa observed on (A) precolonized vertical and (B) horizontal planks. Horizontal planks were placed at midintertidal level ( $2.90 \mathrm{~m}$ above LWST) 
Table 1. Semibalanus balanoides. Split-plot ANOVA without replication examining the effects of site, intertidal level and precolonized plank treatment on the number of newly settled cyprids collected on vertical planks in settlement Expt 1 . Settlement data were log-transformed. Error terms used in the analysis are explained in the 'Data analysis' section. The interaction effect between treatment and intertidal level was examined using the LS Means test. Treatments are presented in increasing number of newly settled cyprids for a given intertidal level. Non-significant differences among treatments are underlined

\begin{tabular}{|c|c|c|c|c|c|c|}
\hline \multicolumn{2}{|c|}{ Source of variation } & Type III SS & $d f$ & MS & $F$ & $\mathrm{p}$ \\
\hline \multicolumn{2}{|l|}{ Site } & 0.2448 & 2 & 0.1224 & 0.66 & 0.5661 \\
\hline \multicolumn{2}{|c|}{ Intertidal level } & 80.3234 & 2 & 40.1617 & 216.01 & 0.0001 \\
\hline \multicolumn{2}{|c|}{ Site $x$ intertidal level (error term for site and intertidal level factors) } & 0.7437 & 4 & 0.1859 & \multicolumn{2}{|c|}{ No test possible } \\
\hline \multicolumn{2}{|c|}{ Plank treatment } & 7.6564 & 3 & 2.5521 & 4.26 & 0.0194 \\
\hline \multicolumn{2}{|c|}{ Plank treatment $x$ intertidal level } & 14.8361 & 6 & 2.4727 & 4.13 & 0.0089 \\
\hline \multicolumn{2}{|c|}{$\begin{array}{l}\text { Site } \times \text { plank treatment }+ \text { site } \times \text { plank treatment } \times \text { intertidal level } \\
(\text { error term for plank treatment factor and plank treatment } \\
\quad \times \text { intertidal level interaction) }\end{array}$} & 10.7890 & 18 & 0.5994 & \multicolumn{2}{|c|}{ No test possible } \\
\hline Corrected total & & 114.5934 & 35 & & & \\
\hline \multicolumn{7}{|l|}{ Interaction } \\
\hline Intertidal level & Treatments & & & & & \\
\hline High & VV UV HV VUD & & & & & \\
\hline Mid- & VUD UV VV HV & & & & & \\
\hline Low & UV VUD HV VV & & & & & \\
\hline
\end{tabular}

uncleared quadrats (Fig. 11). This was particularly true at mid-and low intertidal levels. Within a given level, the difference between cleared and uncleared quadrats increased with decreasing intertidal level. This apparent interaction effect between the experimental treatment and the intertidal level was significant (Table 3).

Table 2. Semibalanus balanoides. Split-plot ANOVA without replication examining the effects of site, intertidal level, precolonized plank treatment and plank section on the number of settled cyprids collected on horizontal planks in settlement Expt 2. Settlement data were log-transformed. Error terms used in the analysis are explained in the 'Data analysis' section. The triple interaction effect was examined using the LS Means test. Treatments are presented in increasing number of newly settled cyprids for a given intertidal level and plank section. Non-significant differences among treatments are underlined

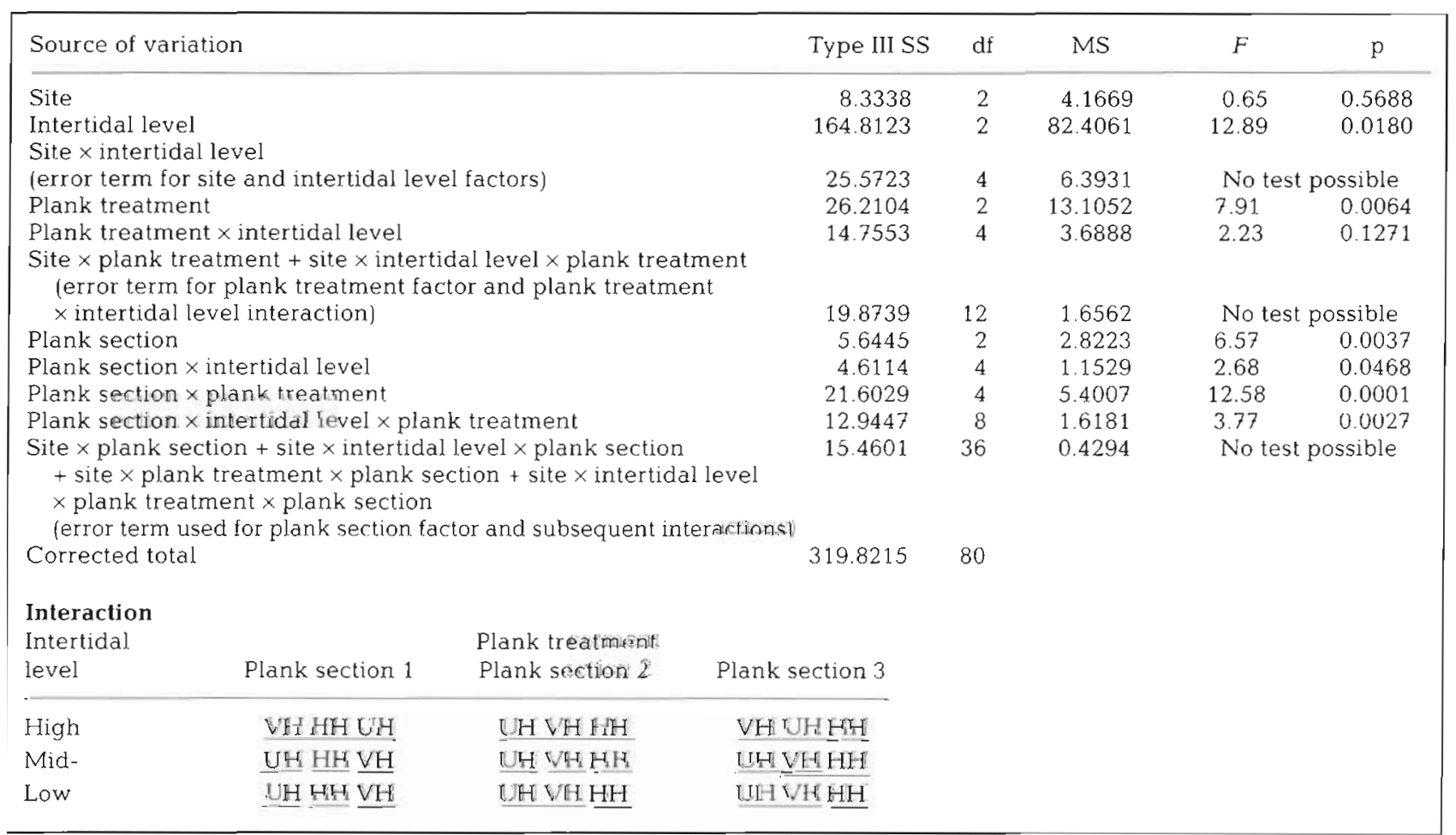




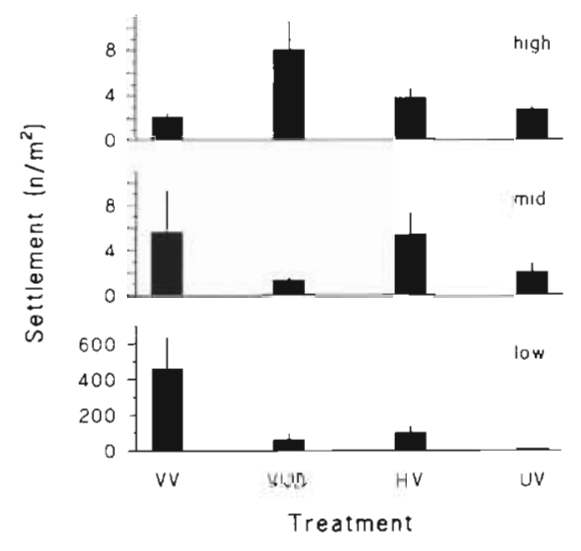

Fig. 7. Density (mean $\pm S E_{;} n=3$ ) of newly settled cyprids of Semibalanus balanoides observed on vertical plank treatments (VV: vertically precolonized planks placed in the same position, VUD: vertically precolonized planks turned upside down, HV: horizontally precolonized control planks, UV: vertical virgin control planks) at high, mid-, and low intertidal levels (sites are used as replicates)

Moreover, results showed that variations due to the experimental treatment and the intertidal level varied on a day-to-day basis. These variations related to treatment $x$ day and intertidal level $x$ day interactions were also highly significant (Table 3 ). However, no triple interaction between all 3 factors was observed (Table 3). The temporal correlation measured between settlement data slowly disappears when settlement data are spaced further apart (first order auto-correla-

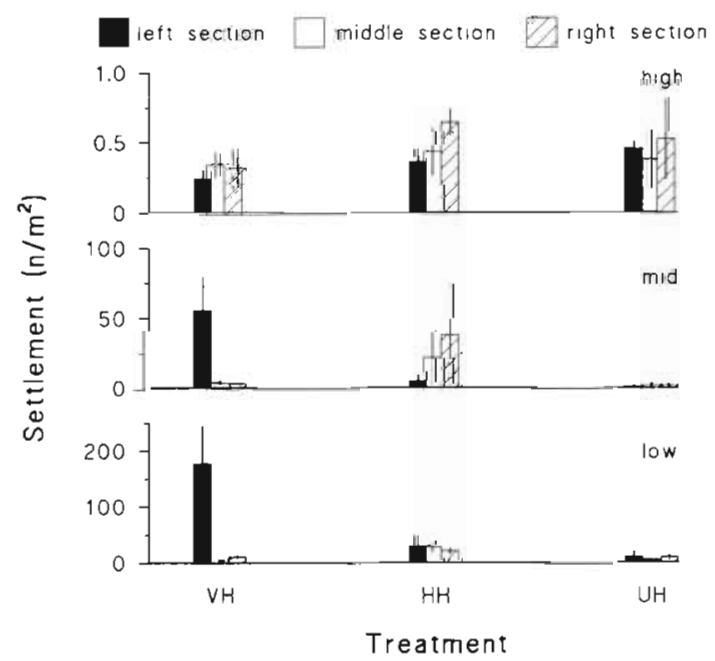

Fig. 8. Density (mean $\pm \mathrm{SE} ; \mathrm{n}=3$ ) of newly settled cyprids of Semibalanus balanoides observed on horizontal plank treatments (VH: vertically precolonized planks, HH: horizontally precolonized planks, UH: horizontal virgin control planks) at high, mid-, and low intertidal levels. Data are presented for each plank section (sites are used as replicates)
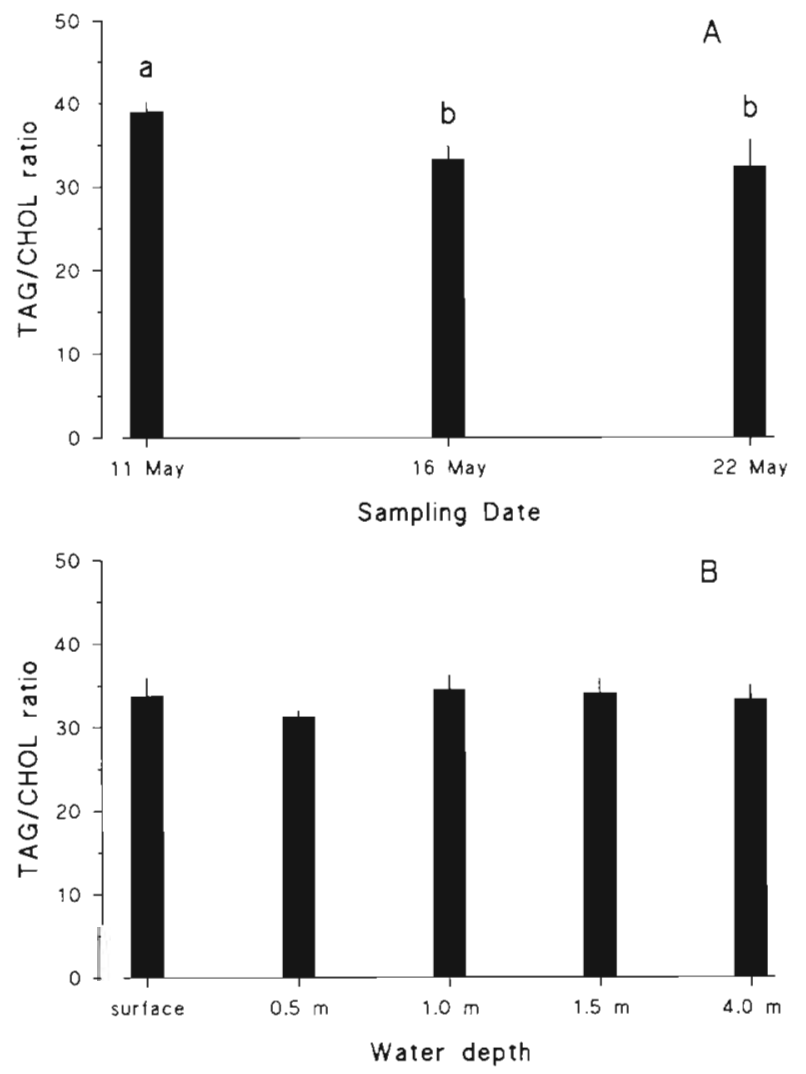

Fig. 9. (A) Temporal and (B) spatial variations of the TAG/ CHOL ratio (means $\pm \mathrm{SE}_{j} \mathrm{n}=3$ ) of planktonic cyprids of Semibalanus balanoides. Temporal variations were determined with cyprids collected at $4 \mathrm{~m}$. Spatial variations were determined using cyprids sampled on 16 May at all 5 given depths. Results having dissimilar letters differ significantly from each other (LS Means test)

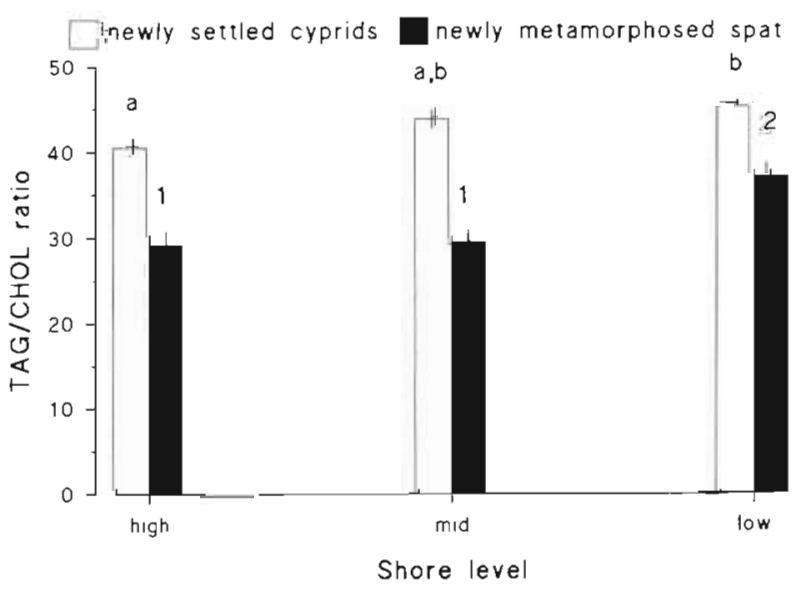

Fig. 10. Spatial variation of the TAG/CHOL ratio (means \pm SE: $\mathrm{n}=3$ ) of newly settled cyprids and newly metamorphosed spat. Samples were collected on 7 May. Results having dissimilar letters (newly settled cyprids) or numbers (newly metamorphosed spat) differ significantly from each other (LS Means test) 


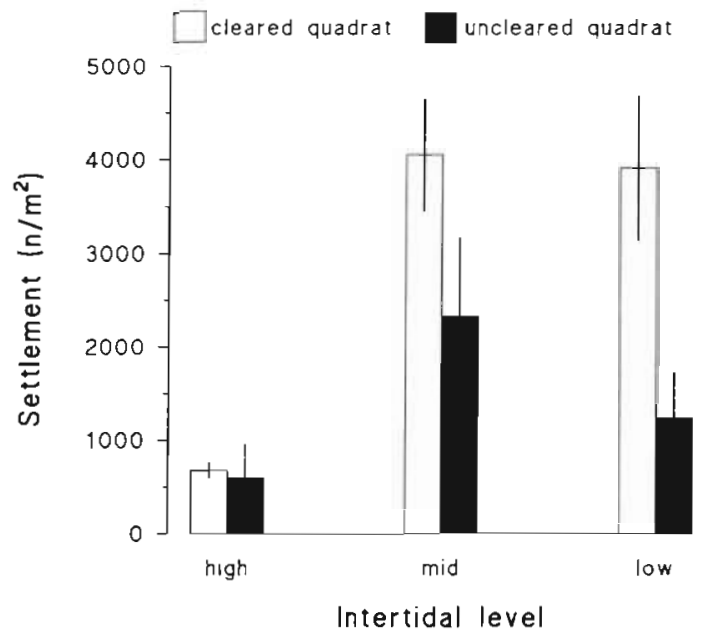

Fig. 11. Density (mean $\pm \mathrm{SE}_{i} \boldsymbol{n}=3$ ) of newly settled cyprids of Semibalanus balanoides observed in cleared and uncleared quadrats at high, mid-, and low intertidal levels

tion: 0.7308 ; Table 3). For example, the correlation observed between settlement data separated by 1,7 and $14 \mathrm{~d}$ were $0.731\left(0.73^{1}\right), 0.111\left(0.73^{7}\right)$ and 0.001 $\left(0.73^{14}\right)$.

Early post-settlement mortality was generally lower in cleared quadrats than in uncleared ones (Fig. 12). This, again, was particularly true at mid- and low intertidal levels. At the high intertidal level, mortality in cleared quadrats was similar to all levels of uncleared quadrats. The ANOVA results showed no direct effect of intertidal level on early post-settlement mortality (Table 4). The interaction between treatment and intertidal level was, however, significant, confirming that variations due to treatments were levelspecific.

Table 3. Semibalanus balanoides. Repeated-measures ANOVA examining the effect of cleared and uncleared treatments, intertidal level and sampling day (temporal dependence) on the number of newly settled cyprids. Square root transformations were applied to all settlement data. See the 'Data analysis' section for details concerning the analysis (ndf: source of variations degree of freedom; ddf: degree of freedom in relation to sampling days [repeated-measures])

\begin{tabular}{|lcccc|}
\hline Source of variation & ndf & ddf & Type III $F$ & $\mathrm{p}$ \\
\hline Treatment & 1 & 12 & 21.23 & 0.0006 \\
Intertidal level & 2 & 12 & 31.29 & 0.0001 \\
Treatment $\times$ intertidal level & 2 & 12 & 4.21 & 0.0411 \\
Sampling day & 16 & 192 & 14.47 & 0.0001 \\
Treatment $\times$ sampling day & 16 & 192 & 2.40 & 0.0027 \\
Intertidal level $\times$ sampling day & 32 & 192 & 2.29 & 0.0003 \\
Treatment $\times$ intertidal level $\times$ sampling day & 32 & 192 & 0.91 & 0.6178 \\
Covariance parameter estimates (SAS Mixed model procedure) & \\
Residual variance & \multicolumn{5}{c}{0.0858} \\
First order auto-correlation & \multicolumn{5}{c}{ (S308 } \\
\end{tabular}

\section{DISCUSSION}

\section{Influence of larval supply}

Newly settled cyprid abundance of the barnacle Semibalanus balanoides peaked when numbers of planktonic cyprids were highest (17 May). Planktonic cyprids were found $60 \%$ of the time at depths within $3.0 \mathrm{~m}$ from the bottom, while more than $90 \%$ of all newly settled cyprids colonized the lower section of planks. Overall, $76 \%$ of the variability in the abundance of newly settled cyprids in the low intertidal level was explained by variations in larval abundance near the bottom (Table 5). Variation in the latter variable also explained low intertidal recruitment (abundance of newly metamorphosed spat) reasonably well. The correlation between recruitment and settlement at the low intertidal level was similar to the correlation between settlement and the abundance of planktonic cyprids at corresponding levels in the water column (Table 5). This implies that the position of cyprids in the water column strongly influenced the settlement intensity and, ultimately, recruitment. These results agreed with the tight spatial positive relationship previously seen between planktonic cyprid distribution and cyprid settlement in other areas (e.g. de Wolf 1973, Grosberg 1982, Caffey 1985, Gaines et al. 1985, Minchinton \& Scheibling 1991). Minchinton \& Scheibling (1991), working with $S$. balanoides on the eastern coast of Canada (Sandy Cove, Nova Scotia), showed that over $62 \%$ of the variability in abundance of newly settled cyprids at low shore levels could be explained by planktonic larval abundance near the bottom. We confirmed the importance of larval supply in regulating the distribution and abundance of settlers on the shore. Moreover, the increasing number of newly settled cyprids with decreasing intertidal level on HV planks in the settlement experiment tended to support the theory of differential larval supply, since the periphytic community was homogenous over the plank. Recruitment estimates are only valid with adequate larval supply predictors. Miron et al. (1995), for example, presented separate correlations between numbers of planktonic cyprids from 3 different depths and the number of newly settled cyprids at 3 intertidal levels for $S$. balanoides. In their study, the highest $r$ was between planktonic cyprid numbers near the bottom and the number of newly settled cyprids in the lower intertidal level. All other comparisons were not significant, em- 


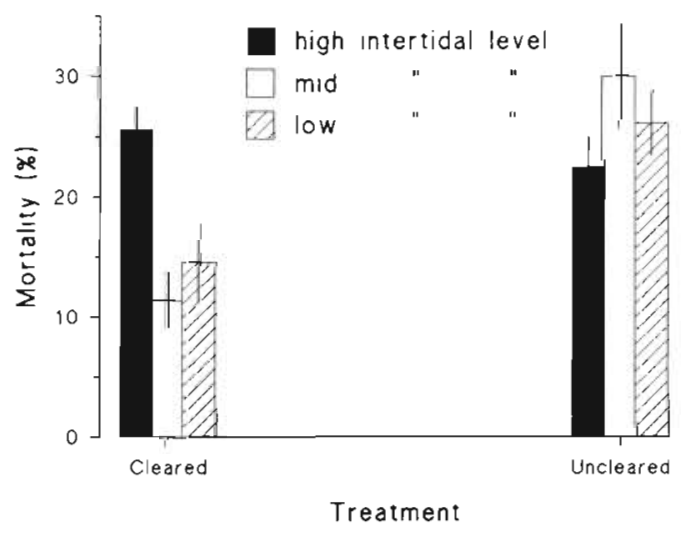

Fig. 12. Early post-settlement mortality (mean percentage $\pm \mathrm{SE}$; $\mathrm{n}=3$ ) of Semibalanus balanoides observed in quadrats cleared and uncleared of adult individuals at high, mid-, and low intertidal levels

phasizing the importance of spatio-temporal variability in planktonic distribution in avoiding spurious correlations.

In this study, the vertical distribution of cyprids in the water column varied over $24 \mathrm{~h}$. Different day/night hydrodynamic regimes during the observation period (17 May) were probably responsible. Over that day, the water was well mixed during daylight hours (e.g. lowest high tide recorded during the sampling period and presence of moderate winds). Cyprids were also found distributed throughout the water column. We do not have additional day/night data to confirm the 17 May pattern of temporal distribution.

There was significant timing between cyprid abundance in the water column and settlement. Within a $3 \mathrm{~d}$ window centred around $17 \mathrm{May}$, we counted over $80 \%$ of the total number of planktonic cyprids of the

Table 4. Semibalanus balanoides. Two-way ANOVA examining the ef fect of cleared and uncleared treatments and intertidal level on early post-settlement mortality. Arcsin tranformations were used on all mortality data. The interaction effect was examined using the LS Means test. Intertidal levels are presented in increasing mortality \% for a given treatment. Non-significant differences among intertidal levels are underlined

\begin{tabular}{|c|c|c|c|c|c|}
\hline Source of variation & SS & df & MS & $F$ & $\mathrm{p}$ \\
\hline Treatment & 0.0615 & 1 & 0.0615 & 14.01 & 0.0028 \\
\hline Intertidal level & 0.0106 & 2 & 0.0053 & 1.21 & 0.3331 \\
\hline Treatment $\times$ intertidal level & 0.0588 & 2 & 0.0294 & 6.71 & 0.0111 \\
\hline Error & 0.0526 & 12 & 0.0044 & & \\
\hline Corrected total & 0.1835 & 17 & & & \\
\hline Interaction & \multirow{2}{*}{\multicolumn{5}{|c|}{ Intertidal level }} \\
\hline Treatment & & & & & \\
\hline Cleared & \multicolumn{5}{|c|}{ Mid Low High } \\
\hline Uncleared & \multicolumn{5}{|c|}{ High Low Mid } \\
\hline
\end{tabular}

entire study period. Within the same period, about $43 \%$ of all settlement occurred. This striking synchrony needs to be investigated in relation to its adaptive value in boreal and temperate regions (e.g. reproductive outputs of adults, short dispersal, time-limited habitat selection behaviour). The 1993 settlement period was a very good year for Semibalanus balanoides in terms of planktonic and newly settled cyprid abundance and recruitment (Boudreau \& Bourget pers. obs.).

\section{Influence of selection of habitat}

Settlement on vertically precolonized planks (VV planks) showed that cyprids of Semibalanus balanoides preferentially settled at low intertidal level. Though differential larval supply can explain this, settlement patterns on the different precolonized transplant surfaces indicated that habitat selection behaviour also played a major role in settled cyprid distribution.

Habitat cues influence barnacle settlement (e.g. Crisp 1974, Gabbott \& Larman 1987, Hui \& Moyse 1987, Bourget 1988). Among these cues, periphyton (or microflora) has been linked to cyprid settlement sites (Strathmann et al. 1981, Hudon et al. 1983, Le Tourneux \& Bourget 1988). In this study, we identified 2 major constituents of the periphyton community, diatoms and a green filamentous alga. All diatoms (Cocconeis, Navicula, Striatella, and Synedra spp.), except for Achnanthes sp., decreased with decreasing intertidal levels. The filamentous green alga Ulothrix sp. was the only species that increased with decreasing intertidal level. The significant decrease in cyprid abundance on the lower portion of vertical planks installed upside down (inverse periphyton gradient) indicated that cyprids actively avoided or were unable to settle at certain sites (almost 7 times fewer cyprids were observed on VUD planks than on VV planks). Thus, high intertidal substrata (low \% cover of Ulothrix sp.) repositioned in a low intertidal environment with high larval supply were poorly colonized. At the same time, low intertidal substrata (high $\%$ cover of Ulothrix sp.) repositioned in a high intertidal environment had increased colonization, though not significantly, possibly due to low larval supply. The importance of habitat cues for settling cyprids was also reflected in HV planks, which tended to be colonized by greater numbers of newly settled cyprids than UV planks, regardless of intertidal level. The horizontal plank experiments showed these same trends. The left sections of planks, originally precolonized at low intertidal levels (VH planks), were sig- 
nificantly more colonized than other sections. On horizontally precolonized planks (no periphyton gradient), settlement was uniform over the planks. Uncolonized controls were generally poorly colonized. The horizontal plank experiment allowed us to control 'larval supply' at a given level, whereas the vertical plank experiment did not. Overall, about $40 \%$ of the variability of newly settled cyprid abundance in the lower intertidal was explained by the \% cover of Ulothrix sp. (Table 5).

Proper habitat cues enhanced settlement, even at sites with high larval supply. Le Tourneux \& Bourget (1988), working in the same area, suggested that Semibalanus balanoides cyprids used Achnanthes parvula as a cue during broad exploration to avoid lethal levels in the intertidal zone. Our study showed that the green alga Ulothrix sp. might play this role as well. Both Achnanthes and Ulothrix spp. colonize the same shore levels but since Ulothrix sp. usually colonizes the shore before Achnanthes sp. (Russell 1971), this apparent contradiction could be due to successional events. Alternatively, cyprids could avoid other diatom species, particularly Cocconeis, Navicula, and Synedra spp. However, the morphology of the filamentous Ulothrix sp. may have better water retention properties at low tide (higher wetness), increasing the quality of settlement sites for cyprids (Strathmann \& Branscomb 1979). Ulothrix sp. may also increase the benthic boundary layer thickness and facilitate larval maintenance on the substratum during exploration. We did not identify the exact habitat cue driving settlement since that type of study would be more easily conducted in the laboratory. Instead, the experiments were designed to evaluate the importance of selection of habitat on distribution and abundance of $S$. balanoides in the field. The impact of the bacterial component, which was not

Table 5. Semibalanus balanoides. Summary of results from linear correlations between different sets of variables at corresponding low levels. $\mathrm{PC}=$ planktonic cyprid near the bottom (i.e. $\geq 1.5 \mathrm{~m}$ depth), NSC = newly settled cyprid at low intertidal level, NMS = newly metamorphosed spat at low intertidal level, $a b=$ abundance, $\mathrm{pc}=$ physiological condition, EPSM = early post-settlement mortality. See 'Data analysis' section for detals of relationships

\begin{tabular}{|lcccc|}
\hline Variables compared & $\mathrm{r}$ & $\mathrm{r}^{2}$ & $\mathrm{df}$ & $\mathrm{p}$ \\
\hline PCab vs NSCab & 0.87 & 0.76 & 8 & 0.003 \\
PCab vs NMSab & 0.71 & 0.51 & 8 & 0.022 \\
NSCab vs NMSab & 0.91 & 0.83 & 8 & 0.001 \\
$\quad \begin{array}{l}\text { Ulothrix sp. relative } \\
\quad \text { abundance (\%) vs NSCab }\end{array}$ & 0.65 & 0.42 & 8 & 0.044 \\
PCpc vs NSCpc & 0.18 & 0.03 & 7 & 0.613 \\
PCpc vs NMSpc & 0.20 & 0.04 & 7 & 0.585 \\
NSCpc vs NMSpc & 0.68 & 0.46 & 7 & 0.046 \\
NSCpc vS EPSM & 0.98 & 0.95 & 1 & 0.122 \\
NMSpc vs EPSM & 0.97 & 0.94 & 1 & 0.149 \\
\hline
\end{tabular}

studied in the present study, is also known to have an effect on barnacle settlement (e.g. Strathmann et al. 1981, Grosberg 1982, Wieczorek et al. 1995). However, it is reasonable to believe that bacterial films probably co-vary with microalgae.

\section{Influence of larval physiological condition}

We showed that the physiological condition of planktonic larvae (TAG/CHOL ratio) decreased with time. This is consistent with the fact that barnacle cyprids do not feed and that neutral lipid content will decrease with time, energetic reserves for swimming and exploration being gradually exhausted (Holland \& Walker 1975, Waldock \& Holland 1978, Lucas et al. 1979). The difference in the physiological condition between newly settled cyprids and newly metamorphosed spat (sampled on the same day) confirmed the high energy cost of settlement and metamorphosis (Waldock \& Holland 1978, Lucas et al. 1979). The temporal variation of the physiological condition of cyprids suggests that there might be an optimal settlement window during the planktonic phase of cyprids. Larvae of many marine benthic invertebrate species are time-limited with respect to optimal selection of habitat (Rittschof et al. 1984, Pechenik 1990, Boudreau et al. 1993b). The strong temporal correspondence between planktonic cyprid abundance and settlement peaks on 17 May supports the hypothesis that settlement is time-limited once larvae are competent. These results should be interpreted with caution since the mean TAG/CHOL ratio values measured in planktonic cyprids were lower than in newly settled cyprids. However, the plankton samples were collected later than newly settled cyprids from pilings (between 11 and 22 May vs 7 May) and the physiological condition of cyprids decreased rapidly over time.

The physiological index for planktonic cyprids was uniform throughout the water column, but the index for settled cyprids and newly metamorphosed spat increased with decreasing intertidal level. Thus, we found no significant correlations between the condition of planktonic cyprids and newly settled cyprids, or between the condition of planktonic cyprids and newly metamorphosed spat (Table 5). The lack of significant correlations between the physiological condition of planktonic cyprids and both newly settled cyprids and newly metamorphosed spat may have been influenced by moderate winds on 16 May, which may have mixed the larvae throughout the water column. However, we explained about $46 \%$ of the variability in the condition of newly metamorphosed spat by variation in the physiological index of newly settled cyprids. The viability of many invertebrate larvae is positively correlated with 
neutral lipid content (Helm et al. 1973, Lucas et al. 1979, Gallager \& Mann 1981, Gallager et al. 1986, Ouellet et al. 1992) and higher energy reserves (Holland \& Walker 1975). In this study, cyprids that settled at low intertidal levels were in the best condition and had lower early post-settlement mortality rates. Variation in the physiological condition of newly settled cyprids and newly metamorphosed spat, although not significant with 1 degree of freedom, explained 95 and $94 \%$ of the variability in early post-settlement mortality, respectively (Table 5).

Overall, these results suggest that planktonic cyprids in the best physiological condition preferentially settled on optimal sites (e.g. low intertidal levels), compared to those in poor condition. We cannot rule out entirely early post-settlement processes (e.g. desiccation) which may have selectively decreased TAG/CHOL ratios once cyprids settled, though it is unlikely since both newly settled cyprids and newly metamorphosed spat were collected within $1 \mathrm{~h}$ after the water level had dropped enough for sampling.

\section{Influence of space availability and early post-settlement mortality}

In the space availability experiment, the density of settled cyprids on pilings was generally greater in cleared than in uncleared quadrats, particularly at mid-and low intertidal levels. Gaines et al. (1985), and more recently Minchinton \& Scheibling (1993), have suggested that settlement is, along with other factors (e.g. larval supply, local hydrodynamics, intertidal height), related to the availability of free space. We found that the difference between densities in cleared versus uncleared quadrats increased with decreasing intertidal level. At high intertidal levels, the low larval supply might explain the lack of differences among treatments. In contrast, the fewer settlers on uncleared quadrats at low intertidal levels may have been related to avoidance of crowded sites by cyprids. Chabot \& Bourget (1988) showed that settlement of Semibalanus balanoides at St. Andrews increased with increasing adult cover up to a threshold value of about $25 \%$, above which settler abundance declined. In this study, the $\%$ cover of adults in the quadrats was 50 to $75 \%$. At mid-intertidal levels, the number of adults occupying the pilings was lower than at low intertidal levels.

The availability of space also led to differential early post-settlement mortality. Mortality was around 25\% in uncleared quadrats regardless of intertidal level. Similar values were observed for cleared quadrats at high intertidal level. However, mortality decreased to $10-15 \%$ for cleared quadrats at mid-and low intertidal levels. Minchinton \& Scheibling (1993) showed that mortality was relatively constant (20 to $25 \%$ ) with intertidal height in control treatments. In their study, barnacle removal did not significantly influence mortality at mid- and high intertidal levels. The similar mortality values in the present study in cleared and uncleared treatments suggest that environmental pressures (e.g. desiccation stress) are an important cause of mortality at high intertidal levels. In contrast, the large difference between mortalities in both treatments at mid-and low intertidal levels suggest density-dependent mortality at lower levels. However, this was unexpected given the short time period considered. The settlement behaviour of Semibalanus balanoides in relation to adult conspecifics needs further investigation. Direct video observations of juvenile/ adult stages and settling cyprids of the barnacle Balanus amphitrite have shown that barnacles are able to clean their parietes, as well as their immediate vicinity, of settling cyprids (Walters \& Miron pers. obs.).

\section{CONCLUSIONS}

In the St. Lawrence system and Atlantic coast of Canada, the distribution of the barnacle Semibalanus balanoides is patchy and vertically limited (Bousfield 1955, Chabot \& Bourget 1988, Le Tourneux \& Bourget 1988, Minchinton \& Scheibling 1991). A number of studies on different barnacle species have suggested that larval supply, selection of habitat, availability of space and early post-settlement mortality were the main components regulating the distribution and abundance of recruits on the shore. However, the influence of these factors is usually examined independently. In the present study, these factors were simultaneously examined through a multiple working hypotheses approach. This approach allowed different alternative models to be investigated within a single experimental field study. Although we recognized that our interpretation is based on a single settlement season, this proved to be a powerful design to study distribution and abundance of intertidal sessile organisms. We have demonstrated that cyprid supply, selection of habitat, availability of space, and early post-settlement mortality are significant in determining early recruitment success of $S$. balanoides. We also showed that conceptual models would be better if a measure of the physiological condition of larvae were included. The optimal settlement period, vertical position, and selection of habitat in marine benthic invertebrate larvae are all related to endogenous factors such as the larval physiological condition.

Acknowledgements. Funding for this research was provided by NSERC and FCAR grants to E.B. GIROQ and Université 
Laval provided a post-doctoral fellowship to G.M., and NSERC a post-doctoral fellowship to B.B. We thank D. Blanchard, L. Lapointe, and E. Pilote for their help in the field. We also thank $L$. Fortier for the use of his Iatroscan analyser and G. Bergeron for technical laboratory assistance. A. Cardinal confirmed the identification of the periphyton and P. Gagné determined the abundance of periphyton. G. Daigle and C. Lovejoy provided statistical and linguistic improvements, respectively. We would also like to thank the referees for their constructive comments, particularly referee no. 2 , who was alert enough to factor out certain statistical problems. This is a contribution to the program of GIROQ (Groupe interuniversitaire de Recherches océanographiques du Québec).

\section{LITERATURE CITED}

Ackman RG, McLeod CA, Banerjee AK (1990) An overview of analyses by chromarod-Iatroscan TLC-FID. J Planar Chromatol 3:450-489

Bertness MD, Gaines SD, Stephens EG, Yund PO (1992) Components of recruitment in populations of the acorn barnacle Semibalanus balanoides (Linnaeus). J Exp Mar Biol Ecol 156:199-215

Boudreau B, Bourget E, Simard Y (1990) Benthic invertebrate larval response to substrate characteristics at settlement: shelter preferences of the American lobster Homarus americanus. Mar Biol 106:191-198

Boudreau B, Bourget E, Simard Y (1993a) Behavioural responses of competent lobster postlarvae to odor plumes. Mar Biol 117:63-69

Boudreau B, Bourget E, Simard Y (1993b) Effect of age, injury, and predator odors on settlement and shelter selection by lobster Homarus americanus postlarvae. Mar Ecol Prog Ser 93:119-129

Bourget $E$ (1988) Barnacle larval settlement: the perception of cues at different spatial scales. In: Chelazzi $G$, Vannini $M$ (eds) Behavioural adaptations to intertidal life. Plenum Publishing Corporation, New York, p 153-172

Bousfield EL (1955) Ecological control of the occurrence of barnacles in the Miramichi estuary. Bull Natl Mus Can $137: 1-69$

Caffey HM (1985) Spatial and temporal variation in settlement and recruitment of intertidal barnacles. Ecol Monogr 55:313-332

Chabot R, Bourget E (1988) Influence of substratum heterogeneity and settled barnacle density on the settlement of cypris larvae. Mar Biol 97:45-56

Chamberlin TC (1965) The method of multiple working hypotheses. Science 148:754-759

Connell JH (1961) Effects of competition, predation by Thais lapillus, and other factors on natural populations of the barnacle Balanus balanoides. Ecol Monogr 31:61-104

Connell JH (1970) A predator-prey system in the marine intertidal region. I. Balanus glandula and several species of Thais. Ecol Monogr 40:49-78

Connell JH (1975) Some mechanisms producing structure in natural communities: a model and evidence from field experiments. In: Cody ML, Diamond JM (eds) Ecology and evolution of communities. Belknap, Cambridge, p 460-490

Connell JH (1985) The consequences of variation in initial settlement vs. post-settlement mortality in rocky intertidal communities. J Exp Mar Biol Ecol 93:11-45

Crisp DJ (1974) Factors influencing the settlement of marine invertebrate larvae, In: Grant PT, Mackie AM (eds) Chemoreception in marine organisms. Academic Press, London, p 177-265
Dayton PK (1971) Competition, disturbance, and community organization: the provision and subsequent utilization of space in a rocky intertidal community. Ecol Monogr 41: $351-389$

de Wolf P (1973) Distribution and dispersal of barnacle larvae. Neth J Sea Res 6: 1-112

Fraser AJ (1989) Triacylglycerol content as a condition index for fish, bivalve, and crustacean larvae. Can J Fish Aquat Sci 46:1868-1873

Gabbott PA, Lamman VN (1987) The chemical basis of gregariousness in cirripedes: a review. In: Southward AJ (ed) Barnacle biology. AA Balkema, Rotterdam, p 377-387

Gaines SA, Brown S, Roughgarden J (1985) Spatial variation in larval concentration as a cause of spatial variation in settlement for the barnacle, Balanus glandula. Oecologia $67: 267-272$

Gaines SD, Roughgarden J (1985) Larval settlement rate: a leading determinant of structure in an ecological community of the marine intertidal zone. Proc Natl Acad Sci USA 82:3707-3711

Gallager SM, Mann R (1981) The use of specific staining to monitor condition in bivalve larvae in large scale cultures. J Shellfish Res 1:69-73

Gallager SM, Mann R (1986) Growth and survival of larvae of Mercenaria mercenaria (L.) and Crassostrea virginica (Gmelin) relative to broodstock conditioning and lipid content of eggs. Aquaculture 56:105-121

Gallager SM, Mann R, Sasaki GG (1986) Lipid as an index of growth and viability in three species of bivalve larvae. Aquaculture 56:81-103

Grosberg RK (1982) Intertidal zonation of barnacles: the influence of planktonic zonation of larvae on vertical distribution of adults. Ecology 63:894-899

Grosberg RK, Levitan DR (1992) For adults only? Supply-side ecology and the history of larval biology. Trends Ecol Evol $7: 130-133$

Hadfield MG (1986) Settlement and recruitment of marine invertebrates: a perspective and some proposals. Bull Mar Sci 39:418-425

Helm MM, Holland DL, Stephenson RR (1973) The effect of supplementary algal feeding of a hatchery breeding stock of Ostrea edulis L. on larval vigour. J Mar Biol Assoc UK $53: 673-684$

Holland DL (1978) Lipid reserves and energy metabolism in the larvae of benthic marine invertebrates. In: Malins DC, Sargent JR (eds) Biochemical and biophysical perspectives in marine biology. Academic Press, London, p 85-123

Holland DL, Walker G (1975) The biochemical composition of the cypris larva of the barnacle Balanus balanoides L. $J$ Cons Int I'Explor Mer 36:162-165

Hudon C. Bourget E, Legendre P (1983) An integrated study of the factors influencing the choice of the settling site of Balanus crenatus cyprid larvae. Can J Fish Aquat Sci 40: $1186-1.194$

Hui E, Moyse J (1987) Settlement patterns and competition for space. In: Southward AJ (ed) Barnacle biology. AA Balkema, Rotterdam, p 363-376

Hunt HL, Scheibling RE (1997) Role of early post-settlement mortality in recruitment of benthic marine invertebrates. Mar Ecol Prog Ser 155:269-301

Keough MJ, Downes BJ (1982) Recruitment of marine invertebrates: the role of active larval choices and early mortality. Oecologia 54:348-352

Kirk RE (1982) Experimental design: procedures for the behavioral sciences. Brooks/Cole, Pacific Grove

Le Tourneux F, Bourget E (1988) Importance of physical and 
biological settlement cues used at different spatial scales by the larvae of Semibalanus balanoides. Mar Biol 97 $57-66$

Lewin R (1986) Supply-side ecology. Science 234:25-27

Lucas MI, Walker G, Holland DL, Crisp DJ (1979) An energy budget for the free swimming and metamorphosing larvae of Balanus balanoides (Crustacea: Cirripedia). Mar Biol 55:221-229

Menge BA (1976) Organization of the New England rocky intertidal community: role of predation, competition, and environmental heterogeneity. Ecol Monogr 46:355-393

Menge BA, Sutherland JP (1976) Species diversity gradients: synthesis of the role of predation, competition, and temporal heterogeneity. Am Nat 110:351-369

Menge BA, Sutherland JP (1987) Community regulation: variation in disturbance, competition, and predation in relation to environmental stress and recruitment. Am Nat 130: $730-757$

Mileikovski SA (1971) Types of larval development in marine bottom invertebrates, their distribution and ecological significance: a re-evaluation. Mar Biol 10:193-213

Minchinton TE, Scheibling RE (1991) The influence of larval supply and settlement on the population structure of barnacles. Ecology 72:1867-1879

Minchinton TE, Scheibling RE (1993) Free space availability and larval substratum selection as determinants of barnacle population structure in a developing rocky intertidal community. Mar Ecol Prog Ser 95:233-244

Miron G, Boudreau B, Bourget E (1995) Use of larval supply in benthic ecology: testing correlation between larval supply and larval settlement. Mar Ecol Prog Ser 124:301-305

Miron G, Bourget E, Archambault P (1996) Scale of observation and distribution of adult conspecifics: their influence in assessing passive and active settlement mechanisms in the barnacle Balanus crenatus Brugière. J Exp Mar Biol Ecol 201:137-158

Montgomery DC (1991) Design and analysis of experiments. Wiley, New York

Morse DE (1990) Recent progress in larval settlement: closing the gap between molecular biology and ecology. Bull Mar Sci 46:465-483

Mullineaux LS, Butman CA (1991) Initial contact, exploration and attachment of barnacle (Balanus amphitrite) cyprids settling in flow. Mar Biol 110:93-103

Ouellet P, Taggart CT, Frank KT (1992) Lipid condition and survival in shrimp (Pandalus borealis) larvae. Can J Fish Aquat Sci 49:368-378

Paine RT (1974) Intertidal community structure: experimental studies on the relationship between a dominant competitor and its principal predator. Oecologia 15:93-120

Paine RT (1977) Controlled manipulations in the marine intertidal zone and their contributions to ecological theory. In: Goulden CE (ed) The changing scenes in natural sciences, 1776-1976. Special publication 12, The Academy of Natural Sciences of Philadelphia, Fulton, p 245-270

Pawlik JR (1992) Chemical ecology of the settlement of benthic marine invertebrates. Oceanogr Mar Biol Annu Rev 25:113-165

Pechenik JA (1990) Delayed metamorphosis by larvae of benthic marine invertebrates. Does it occur? Ophelia 32:63-94

Platt JR (1964) Strong inference. Science 146:347-353

Rittschof D, Branscomb ES, Costlow JD (1984) Settlement and behavior in relation to flow and surface in larval barnacles, Balanus amphitrite Darwin. J Exp Mar Biol Ecol 82: $131-146$

Roughgarden J, Gaines SD, Pacala SW (1987) Supply-side ecology: the role of physical transport processes. In: Gee
JHR, Giller PS (eds) Organization of communities: past and present. Blackwell Scientific Press, London, p 491-518

Roughgarden J, Gaines S, Possingham. H (1988) Recruitment dynamics in complex life cycles. Science 241:1460-1466

Russell G (1971) Algae as fouling organisms. In: Organization for economic cooperation and development (ed) Marine borers, fungi and fouling organisms of wood. OECD, Paris, p 125-135

SAS (1988) SAS user's guide: statistics. Version 6.03. SAS Institute, Cary

Scheltema RS (1986) On dispersal and planktonic larvae of benthic invertebrates: an eclectic overview and summary of problems. Bull Mar Sci 39:290-322

Sokal RR, Rohlf FJ (1981) Biometry. WH Freeman, San Francisco

Strathmann RR, Branscomb ES (1979) Adequacy of cues to favorable sites used by settling larvae of two intertidal barnacles. In: Stancyk SE (ed) Reproductive ecology of marine invertebrates. University of South Carolina Press, Columbia, p 77-89

Strathmann RR, Branscomb ES, Veder K (1981) Fatal error in set as a cost of dispersal and the influence of intertidal flora on set of barnacles. Oecologia 48:13-18

Thomas MLH, Arnold DC, Taylor ARA (1983) Rocky intertidal communities. In: Thomas MLH (ed) Marine coastal systems of the Quoddy region, New Brunswick. Can Spec Publ Fish Aquat Sci 64:35-73

Thorson G (1950) Reproductive and larval ecology of marine bottom invertebrates. Biol Rev 25:1-45

Underwood AJ (1990) Experiments in ecology and management: their logics, functions and interpretations. Aust J Ecol 15:365-389

Underwood AJ (1991) The logic of ecological experiments: a case history from studies of the distribution of macro-algae on rocky intertidal shores. J Mar Biol Assoc UK 71:841-866

Underwood AJ (1997) Experiments in ecology. Cambridge University Press, Cambridge

Underwood AJ, Denley EJ (1984) Paradigms, explanations and generalizations in models for the structure of intertidal communities on rocky shores. In: Strong DR, Simberloff D, Abele LG. Thistle AB (eds) Ecological communities: conceptual issues and the evidence. Princeton University Press, Princeton, p 151-180

Underwood AJ, Fairweather PG (1989) Supply-side ecology and benthic marine assemblages. Trends Ecol Evol 4:16-20

Waldock MJ, Holland DL (1978) Fatty acid composition of the triacylglycerols of the cypris larva of the barnacle Balanus balanoides during metamorphosis. Mar Biol 46:163-166

Walters LJ (1992) Field settlement locations on subtidal marine hard substrata: Is active larval exploration involved? Limnol Oceanogr 37:1101-1107

Walters LJ, Miron G, Bourget E (1999) Endoscopic observations of invertebrate larval substratum exploration and settlement. Mar Ecol Prog Ser 182:95-108

Wieczorek SK, Clare AS, Todd CD (1995) Inhibitory and facilitory effects of microbial films on settlement of Balanus amphitrite amphitrite larvae. Mar Ecol Prog Ser 119: $221-228$

Young CM (1987) Novelty of 'supply-side' ecology. Science 235:415-416

Young CM (1990) Larval ecology of marine invertebrates: a sesquicentennial history. Ophelia 32:1-48

Yule AB, Walker G (1987) Adhesion of barnacles. In: Southward AJ (ed) Barnacle biology. AA Balkema, Rotterdam, p 389-402

Zar JH (1984) Biostatistical analysis. Prentice-Hall, Englewood Cliffs

Submitted: January 30, 1998; Accepted: June 22, 1999

Proofs received from author(s): October 26, 1999 